\title{
Etiquetas e comportamentos durante a viagem pastoral de D. Carlos Luiz D'Amour ao sul da diocese de Cuiabá
}

\author{
Etiquette and behavior during D. Carlos Luiz D'Amour's pastoral travel to \\ south of the diocese of Cuiabá
}

Jérri Roberto Marin*

\begin{abstract}
Resumo:
O artigo tematiza a difusão de etiquetas e a reforma dos comportamentos durante a viagem pastoral de D. Carlos Luiz D'Amour ao sul da diocese de Cuiabá, em 1886. A fonte de pesquisa é o diário escrito por seu secretário particular, o cônego Bento Severiano da Luz. Neste diário, foram narrados os percursos, os principais acontecimentos e as realizações da comitiva, sendo o bispo a personagem central. Entre os objetivos da viagem estavam difundir novos padrões de conduta, de sentimentos e de etiqueta, civilizar os mato-grossenses e instaurar a boa sociedade católica. As aparições públicas do bispo assumiam funções simbólicas, ou seja, a afirmação política e religiosa do poder episcopal na sociedade, criando uma imagem sagrada e corporificada em sua pessoa. D. Carlos, no jogo das relações de poderes, viu-se compelido a submeter-se à etiqueta, cujos padrões eram os europeus e os da corte imperial, assim como a exercer pressões para que os diocesanos a cumprissem. Cada detalhe da etiqueta e do cerimonial canônico cumpria a função de autorrepresentação ostentatória de D. Carlos e as suas supressões aboliam as distâncias, as distinções sociais e obliteravam sua autoridade e poder.
\end{abstract}

Palavras-chave: etiqueta; comportamentos; visita pastoral; D. Carlos Luiz D’Amour

\begin{abstract}
:
This article studies the etiquette diffusion and the reform of behavior during the pastoral visit of $D$. Carlos Luiz D'Amour, to the south of the Diocese of Cuiabá, in 1886. The source is the diary written by his private secretary, Canon Bento Severiano da Luz. In this diary, the paths of the party were narrated as well as its major events and achievements, having the bishop as the central character. One of the objectives of the trip was to spread new patterns of behavior, feelings and etiquette, civilize Mato Grosso and establish a good Catholic society. The public appearances of the bishop assumed symbolic functions, i.e., the political and religious affirmation of the episcopal power in society, creating a sacred image embodied in his person. D. Carlos, in the game of power relations, sees himself compelled to submit to the etiquette, whose standards were Europeans and the imperial court, as well as to pressure the diocesans to do the same. Every detail of the etiquette and the canonical ceremonial has fulfilled the function of ostentatious self-representation. His suppression has abolished distances, social distinctions and obliterated his authority and power.
\end{abstract}

Keywords: etiquette; behavior; pastoral visit; D. Carlos Luiz D'Amour

\footnotetext{
Artigo recebido em 03 de junho de 2015 e aprovado em 03 de dezembro de 2015.

* Doutor em História pela UNESP; Prof. Associado da UFMS/Brasil; Prof. da Pós-Graduação em História da UFGD. Bolsista CAPES - Proc. no BEX 2372/15-0, Estágio Sênior junto a Università Degli Studi di Roma "La Sapienza". Pais de origem: Brasil. E-mail: jerrimarin@bol.com.br
}

Horizonte, Belo Horizonte, v. 13, n. 40, p. 2137-2167, out./dez. 2015 - ISSN 2175-5841 


\section{Introdução}

No final do século XIX, no contexto das reformas católicas ${ }^{1}$, as visitas pastorais tornaram-se um dos principais mecanismos de gestão das dioceses e de pedagogia dos fiéis e do clero. Como decorrência, havia exigências de que fossem realizadas com regularidade (VIEIRA, 2007). O Concílio de Trento (1545-1563) estabeleceu os princípios e as práticas para as visitas, cujos fins eram: conhecer a situação religiosa da diocese, difundir a doutrina católica, repreender e combater os desvios dos fiéis e do clero, conservar os bons costumes, exortar a população à pratica religiosa, regularizar a situação dos diocesanos, corrigir os descasos com templos, cemitérios e com os objetos litúrgicos e impor práticas e vivências religiosas centradas nos sacramentos. Nesse sentido, as visitas pastorais eram um importante mecanismo regulador da vida da população, de evangelização, de fiscalização, de reorganização do catolicismo e da administração diocesana.

Pretende-se enfocar neste artigo outras dimensões das visitas pastorais, sobretudo as associadas ao processo civilizatório e educacional, tais como as intervenções para as mudanças dos costumes, dos hábitos e das regras de comportamento social. Esses aspectos serão analisados na viagem pastoral do bispo D. Carlos Luiz D’Amour ao sul da diocese de Cuiabá, em 1886 (MARIN, 2003).

Havia a preocupação de D. Carlos e da comitiva episcopal em instituir uma sociedade civilizada em Mato Grosso a partir das mudanças nos padrões de hábitos, de costumes e de comportamentos dos diocesanos. Os modelos, do que seria um homem civilizado eram emanados da Europa, sobretudo da França e da corte imperial. Havia a percepção por parte das elites, do governo provincial e da hierarquia eclesiástica mato-grossense que a população não era civilizada e que, por meio da educação, da religião, das pressões sociais e das coerções, os seus hábitos, comportamentos e costumes indesejados poderiam ser substituídos por

\footnotetext{
${ }^{1}$ Processo de reforma eclesial iniciado na segunda metade do século XIX cujos preceitos eram os tridentinos e os ultramontanos.
} 
outros, considerados mais polidos, corteses e refinados. Educar, moralizar, disciplinar, intervir, civilizar eram demandas de vários setores da hierarquia eclesiástica brasileira, pois permitiriam naturalizar os bons hábitos, costumes e comportamentos e favorecer, dessa forma, a cristianização, o disciplinamento social e a manutenção da ordem política. O enquadramento dos costumes proporcionaria a uniformização do território e manteria a coesão social e populacional do país (KANTOR, 1996).

Procurou-se salientar também como a etiqueta era compreendida à época e as estratégias adotadas pela comitiva episcopal para controlar os comportamentos, a fim de disseminar novos modelos culturais, tendo em vista a civilização dos mato-grossenses e a instauração da boa sociedade. Também foram analisadas as resistências enfrentadas pela comitiva episcopal.

$\mathrm{O}$ conceito de civilização adotado não se refere às grandes realizações e conquistas humanas, de cunho nacional ou ocidental, mas às condutas ou aos comportamentos humanos, ou seja, "a qualidade social das pessoas, suas habitações, suas maneiras, sua fala, suas roupas" (ELIAS, 1994, p. 24). A etiqueta é compreendida como um conjunto de regras que ordenavam os gestos, as formas de vestir, de agir, de falar, de morar, de lidar com as emoções, entre outras questões; tais regras podem ser desenvolvidas e aperfeiçoadas nas pessoas (ELIAS, 1994, p. 24, 94). As mudanças nos comportamentos, nos padrões de sentimentos e de conduta estão associadas ao entrelaçamento e à interdependência crescentes entre as pessoas, orientando-as e exercendo pressões umas sobre as outras (ELIAS, 1993, p. 54). Segundo Foucault (1979), as práticas de poderes, ao fabricarem o indivíduo educado, recatado e refinado, revelavam seu lado positivo ao aprimorálo, adestrá-lo e civilizá-lo. A etiqueta e o cerimonial também foram criados para instituir, legitimar e instaurar diferenças sociais e privilégios na sociedade, como demonstrou Elias (1993, 1994, 2001). 


\section{Visitar para observar, registrar e intervir: os olhares do Cônego Bento Severiano da Luz sobre o Mato Grosso e suas populações}

D. Carlos Luiz d'Amour foi o segundo bispo a administrar a diocese de Mato Grosso e integrava o elenco dos "bispos reformadores" que foram nomeados a partir da segunda metade do século XIX². Foi o primeiro a realizar visitas pastorais na diocese de Mato Grosso, que era considerada a "maior" do Brasil (LUZ, 1979, p. 67). Em 1886, com 48 anos3, visitou o sul da diocese durante cinco meses e vinte e um dias, quando foram percorridas 650 léguas e vistoriadas as freguesias de Livramento, Poconé, São Luís de Cáceres, Corumbá, Miranda, Santa Rita de Nioaque e as povoações de Vacaria e Campo Grande.

O relatório da viagem pastoral foi escrito em forma de diário por seu secretário particular, o cônego Bento Severiano da Luz, homem de confiança e protegido por D. Carlos (MESQUITA, 1927, p.17)4. Neste diário, foram narrados os principais acontecimentos e as realizações da comitiva e, principalmente, do bispo, que era a personagem central do relato. O relatório foi impresso na Bahia, em um folheto denominado Itinerário da visita pastoral, publicado em 1890, com 265 páginas (MESQUITA, 1927, p. 22). O desejo de glória era um dos maiores anseios de D. Carlos, tendo favorecido as atividades de registro e a publicação de obras que afirmavam seus poderes e suas iniciativas.

As descrições culturais de Luz (1979) foram o resultado de experiências partilhadas no convívio com os outros. Ele mostrava-se curioso a respeito da natureza, da geografia, dos costumes, das manifestações religiosas e de tudo o que acontecia ao seu redor. A tarefa de observar e registrar os acontecimentos da viagem tornava os mato-grossenses objetos centrais de interesse, estudo e reflexão. Todos os indivíduos foram observados, assim como as motivações dos seus

\footnotetext{
${ }^{2}$ D. Carlos foi sagrado bispo de Cuiabá em 28 de abril de 1878, em Salvador, Bahia, assumindo sua administração em 2 de maio de 1879.

${ }^{3}$ Em Poconé, no dia 11 de junho de 1886, D. Carlos completou 49 anos de idade.

${ }^{4}$ Luz era goiano, onde foi seminarista, mas concluiu seus estudos em Cuiabá, sob a proteção de D. Carlos. Ordenou-se em 1882 e logo se tornou secretário particular do bispo, cônego da catedral e professor de português, francês e latim no seminário. Também era escritor e escrevia poemas em português, francês e em latim.
} 
comportamentos, gestos, falas, expressões faciais, posturas corporais, paixões, fraquezas, erros, vestuários, formas de morar, religiosidades, entre outros aspectos. Seu olhar era vigilante e tudo era alvo de registro, interesse e supervisão, a fim de organizar e planejar estratégias eficazes para intervir, disciplinar e reprimir. A presença da comitiva episcopal era um fato de autoridade e de poder, cujo espaço sempre fora construído de forma assimétrica e raramente dialógica.

D. Carlos e o clero que participava da comitiva consideravam-se agentes e vanguardas do processo civilizatório, acreditando estarem em condições de educar e cristianizar as terras e as gentes mato-grossenses. A Igreja Católica, as elites mato-grossenses e o governo provincial também desejavam superar os estigmas de barbárie, alta criminalidade, instabilidade política, atraso religioso e incivilidade, impetrada por viajantes nacionais e estrangeiros e pelos próprios mato-grossenses. Para D. Carlos, a regeneração do Mato Grosso passava obrigatoriamente por uma reforma moral, por meio de uma homogeneização dos comportamentos de acordo com os princípios da Igreja Católica. Para Luz (1979, p. 154), sempre seria "tempo de emendar o passado e cuidar do futuro”. Ou seja, reafirmava-se a importância da Igreja frente ao Estado e à sociedade.

No relatório da viagem pastoral fica evidente a existência de padrões diferentes de moralidades, de sentimentos, de comportamentos e de costumes em Mato Grosso. As experiências e os intercâmbios partilhados não eram entre iguais, uma vez que os contatos sociais e íntimos forçados ocorreram, na maioria das vezes, entre indivíduos de origens sociais e culturais diferentes, instituindo um profundo abismo em relação aos costumes, aos vestuários, aos gestos, aos modos, à mesa e à fala. As hierarquias estavam manifestas na própria comitiva, pois o bispo, o clero e os seminaristas seriam superiores em relação aos demais participantes. Ademais, seriam exemplo da civilização, da cultura e das artes do bem se comportar, das quais a maioria dos mato-grossenses estariam excluídos, pois o refinamento dos eclesiásticos se contrastava com as maneiras bárbaras e incivilizadas dos locais. Num nível inferior, estavam os militares e, abaixo desses, 
os camaradas que compunham a numerosa comitiva ${ }^{\text {. Com essas }}$ autorrepresentações, Luz (1979) construiu e reforçou as distinções sociais e revelou a missão civilizadora da Igreja Católica. O contato e o convívio dessa elite eclesiástica com a população, por sua vez, não seriam negativos, pois eram uma oportunidade para o seu treinamento cultural, político e administrativo, assim como para seu amadurecimento e aperfeiçoamento de condutas e comportamentos. Dessa forma, o seleto e distinto grupo da comitiva episcopal estabeleceu variados níveis de distinção social e exerceu pressões constantes sobre os indivíduos, a fim de reformar os costumes da sociedade e nela naturalizar os novos modelos culturais peculiares à maneira de ser das elites e ao código de costumes vindos da Europa e da corte imperial.

A difusão e a exigência de bons modos estão associadas à ideia de que são necessárias reformas para aprimorar, transformar, educar e refinar os costumes dos indivíduos e da sociedade. Segundo Elias (1993, 1994), o principal critério para definir a direção do processo civilizador é a mudança dos padrões sociais, de comportamentos e de sentimentos. Para difundir o aprimoramento e o refinamento dos costumes, foram necessárias a coerção externa (repreensões, censuras, controles, penalidades, constrangimentos, punições), a fim de que todos se sujeitassem às convenções sociais, e a autocoerção, quando o indivíduo procura refinar os próprios hábitos, costumes e comportamentos, esforçando-se para comportar-se adequadamente. Ao exercitar a educação, a civilidade e a cortesia, por exemplo, o indivíduo deixaria de propagar o desprazer às pessoas do seu convívio, ou seja, sentimentos de asco, repugnância, medo, pecado, etc. Para que esses processos fossem internalizados, deveriam ser ampliadas as vigilâncias, os controles, as cobranças e as punições sobre os indivíduos no convívio social. O aumento das exigências de civilidade impunham a adoção desses modelos culturais por toda a sociedade.

${ }^{5}$ Trabalhadores livres e assalariados. 
Em meio ao jogo político e simbólico, a conduta itinerante do bispo, no contexto pós-Guerra do Paraguai, reafirmava seus direitos de apropriar-se do espaço e das fronteiras de sua extensa diocese. Elias (2001, p. 133), ao analisar a corte de Luís XIV, afirmou que "o povo não acredita em um poder que, embora existindo de fato, não apareça explicitamente na figura de seu possuidor. É preciso ver para crer”. Dessa forma, D. Carlos, em suas aparições, mantinha certo distanciamento em relação às pessoas, o que tinha um fim em si: quanto mais distante se mantivesse, maior seria o respeito que o povo lhe conferiria. Os decretos, as medidas e os atos do bispo, assim como os rituais, as procissões, os adereços litúrgicos e as cerimônias, extrapolavam a encenação e se constituíam num teatro religioso com inúmeros fins, pois tinham uma feição religiosa, social e política. A etiqueta, a cortesia e a afabilidade eram fundamentais e importantes para a eficácia simbólica de afirmação política e religiosa do poder episcopal e para reforçar as diferenciações hierárquicas da sociedade. A pompa, a majestade e o bem representar faziam parte da encenação dos rituais (BLOCH, 1993; ELIAS, 1993, 1994, 2001; GEERTZ, 1985).

D. Carlos, na convivência oficial em sociedade, desempenhava muito bem o seu papel. Ele tinha consciência de si, de seu lugar social e da importância da elevada posição que ocupava na hierarquia eclesiástica brasileira. A autoafirmação social do seu poder, grandeza e prestígio eram indispensáveis para a construção de sua autoimagem na sociedade e exigia uma capacidade de autocoerção constante para evitar erros e falhas pessoais. Na narrativa de Luz (1979), seus comportamentos e atitudes seguiam um cálculo preciso nos gestos, no uso das palavras e nas formalidades. Tudo com naturalidade, sem esforço, com elegância da atitude e amabilidade próprias do seu status. Até no uso do tempo livre demonstrava seu refinamento, pois o utilizava para aperfeiçoar ainda mais sua conduta social distinta, aprimorando sua erudição por meio da leitura e da reflexão, e traçando diretrizes para a sua gestão (LUZ, 1979, p. 69). D. Carlos foi retratado como ocupado permanentemente em múltiplas atividades, 
excepcionalmente dedicado aos negócios da Igreja Católica, do Estado, da diocese e do bem-estar dos diocesanos. A opinião social tinha peso significativo na boa sociedade da época, a partir da qual procurava-se não colocar em risco as identidades de representante da elite eclesiástica e do governo provincial e de D. Pedro II. A etiqueta, o cerimonial e o permanente ar solene construíam a autoapresentação da autoridade episcopal, estando essa posição de poder subjugada à confirmação e aceitação por parte dos outros. Cada detalhe do cerimonial canônico cumpria essa função para que se efetivasse sua autorrepresentação ostentatória.

\section{D. Carlos Luiz D’Amour e a importância da etiqueta para a construção da sua autoridade e da sua imagem}

D. Carlos se submetia à etiqueta e ao cerimonial eclesiásticos, assim como os impunha à sociedade, como forma de preservar a sua autoridade e manter a distância que o separava dos demais indivíduos, assegurando seu poder e prestígio como titular da diocese. Referindo-se ao bispo, Luz (1979, p. 147) afirma que o "cargo sobremodo elevado e alta superioridade social acarreta-lhe, onde quer que esteja, um sem número de conveniências sociais a satisfazer”. A etiqueta também era um instrumento de distanciamento e de dominação cujo fim "acabava sendo ele mesmo, sua existência, sua glória, sua honra” (ELIAS, 2001, p. 132-133). Sua imagem se impõe à sua representação, o que lhe dava garantias de soberania religiosa e de submissão e veneração por parte da população. Por nunca se descuidar, e seguindo as prescrições do Pontifical Romano, apresentava-se em suas aparições oficiais sempre paramentado. Para a celebração das missas ou em compromissos oficiais, trocava suas vestes, tomando os paramentos próprios para cada situação. Em muitas situações, o bispo sacrificou-se para manter a etiqueta que a ocasião exigia, como, por exemplo, nas cerimônias de encomendação dos falecidos, nas quais vestia paramentos pretos, apesar do calor de Mato Grosso, que era um grande fardo, e das distâncias entre as igrejas matrizes e os cemitérios (LUZ, 1979, p. 207-209). Os gestos controlados, a postura ereta e o uso das 
insígnias do poder episcopal seriam expressões da sua civilidade, do lugar social que ocupava na hierarquia eclesiástica e da unidade da Igreja Católica.

D. Carlos tinha um estilo de mando aristocrático e fazia questão de seguir os protocolos da etiqueta e do cerimonial, ajustando suas atitudes, seus olhares, seus gestos, suas falas e seus comportamentos aos objetivos que desejava atingir e, como jogador, tinha uma constante capacidade de previsão. A cada passo, procurava exaltar sua autoridade, suas qualidades e seu papel de líder da Igreja Católica em terras mato-grossenses, sem diferenciar suas ações estatais e privadas. Ou seja, suas aparições sempre eram oficiais e afastavam-se da informalidade. $\mathrm{O}$ desembargador Ernesto Borges testemunhou a Leite (1979, p. 271), que se lembrava de D. Carlos com “as suas vestes talares, rosto cheio, vasta cabeleira branca, contrastando com o solidéu roxo, bem adaptado ao alto da cabeça, porte ereto, levando no braço o báculo, em pausados passos, nas solenes pontificais da Catedral Metropolitana, infundindo respeito e consideração”. D. Carlos empenhava-se em criar esta esfera sagrada corporificada em sua pessoa, autoridade e poder, vistos como legítimos e sobrenaturais. Construía-se, sobretudo, a imagem de um homem sagrado, encantado, santo e distanciado da mundanidade. Geertz (1983, p. 125) evidenciou a importância simbólica deste "teatro da política” para a manutenção do poder. Havia a preocupação de o bispo aparecer sempre de acordo com a sua posição social e de seguir a etiqueta, como instrumento de autoafirmação de sua autoridade sobre a diocese, o Estado e a sociedade.

D. Carlos procurava, em diferentes circunstâncias, difundir vínculos de identificação com o Brasil, com o regime monárquico, com D. Pedro II e com o governo provincial e em difundir o respeito às autoridades constituídas. Faziam parte do cerimonial as continências militares, o toque do hino nacional, o uso de distintivos com as cores nacionais, a inspeção de várias instituições (quartéis, escolas, câmaras municipais), a presença das bandas militares e a audiência com as 
lideranças locais. A Igreja Católica projetava-se como uma instituição fundamental da sociedade, porém subordinada à Constituição e ao Imperador.

Como decorrência, diante da autoridade do bispo, e para demonstrar submissão, exigia-se dos diocesanos o cumprimento da etiqueta e do cerimonial; ou seja, agir de modo refinado e cortês, ter bons modos à mesa, ter gestos comedidos, usar linguagens adequadas e pronunciadas corretamente, ser cavalheiro e gentil, vestir-se adequadamente, entre outros comportamentos. A proximidade forçada que o bispo estabelecia, por meio de inúmeras cerimônias, festejos, cortejos, vistorias e audiências, permitia observar, conhecer e intervir na sociedade, a fim de impor novos modelos culturais, organizar e disciplinar os aspectos religiosos, sociais, políticos, éticos, morais, sexuais, entre outros.

Para Luz (1979, p. 70), os mato-grossenses desconheciam as normas mais elementares de civilidade e os "termos mais comuns de tratar as pessoas". Ao bispo, por exemplo, foram atribuídos vários pronomes de tratamento e raramente o de Vossa Excelência Reverendíssima. Segundo Luz (1979, p. 70), havia alguns "bem lidos, que sabiam-se por umas tangentes sui generis, servindo-se de dizeres latinos e vulgares, pela maior parte truncados, desses que encerram bom senso, graça e concisão". Esses dizeres foram criticados por serem impróprios ao cargo que o bispo ocupava e à sua dignidade, tais como paternidade, alteza, categoria, majestade, compadre, dentre outros (LUZ, 1979, p. 70). Os mato-grossenses, ao tentarem imitar a fala refinada, tornavam-na vulgar e risível. O desconhecimento do uso correto dos pronomes de tratamento, ou seja, a polidez de fachada, foi atribuído à pouca erudição e à ignorância a respeito das regras mais simples de convívio social, como o respeito às autoridades e ao lugar de cada um nas hierarquias. Respeitar a etiqueta era visto como uma exigência vital do convívio social.

Por outro lado, os diocesanos tinham conhecimento de que as pessoas importantes deveriam ser tratadas com respeito às formalidades públicas, ao passo que eles deveriam agir com demonstrações de submissão e veneração, sendo de 
bom tom incluir palavras e dizeres em latim e termos considerados pomposos. Assim, segundo Luz (1979, p. 70), exigia-se a correta sujeição às formalidades da etiqueta e a capacidade de conversar com erudição, tendo em vista instaurar e fazer ser reconhecida a absoluta distância que os separava. D. Carlos, por sua vez, era representado como educado, que sabia comportar-se diante de todos, sempre pronto a receber audiências e sem demonstrar simpatias, antipatias ou preferências.

Para Luz (1979), o refinamento e a educação de D. Carlos faziam com que cativasse a todos, sem distinção de cor, classe social, idade e gênero. Não discriminava também os doentes, inclusive os que teriam doenças contagiosas. $\mathrm{Na}$ cidade de São Luiz de Cáceres, compareceu à residência episcopal um morfético em estado terminal, que desejava ser crismado. Sua presença causou grande alarme e muitas pessoas queriam que ele fosse impedido de ser recebido pelo bispo. O sentimento era de repugnância e de temor de um contágio devido "ao estado adiantado de sua moléstia”. A reação de D. Carlos teria "sufocado o pasmo" coletivo ao receber o "infeliz" de forma atenciosa, sendo uma "grande lição", pois “a santidade evangélica não desdenha ninguém”, sobretudo aqueles que mais precisavam (LUZ, 1979, p. 129-130). A linguagem é pedagógica e de fácil acesso: D. Carlos, como pastor, assemelhado a Jesus Cristo, acolhia a todos, pois todos eram irmãos. Tudo nele inspirava gentileza, cortesia, inteligência e elegância.

Durante a viagem, houve várias tentativas de famílias estabelecerem relações de parentesco com o bispo e com o clero. Era frequente convidá-los para serem padrinhos de batismo de um filho. Acreditava-se que a família e o afilhado, em virtude do compadrio, obteriam um status aos olhos dos outros, o acesso a uma posição social mais privilegiada dentro da sociedade e, sobretudo, o acesso ao círculo mais restrito de amizades do bispo. Como decorrência, chamavam D. Carlos de "seu compadre" e por mais que fossem persuadidos a utilizar o pronome de tratamento correto à dignidade episcopal, recusavam-se a adotá-lo para referirse ao bispo. Luz (1979, p. 70) registrou que um pai tinha "prazer em o chamar 
depois seu compadre, e não perdia vasa; não lhes cabia da boca esse tratamento". Luz (1979) irritava-se com os desvios das normas e procurava preservar as devidas distâncias entre o bispo e o referido pai.

Outro aspecto que desagradava Luz (1979 p. 84, 179, 129) era a má pronúncia das palavras e o uso incorreto do vernáculo, criando situações que, para ele, eram cômicas e lamentáveis. Na fazenda Cotia, durante o terço, um escravo auxiliado por mulheres teria se empolgado nos cantos, pecando no tom e nas pronúncias, vulgarizando a "bela jaculatória Louvado Seja Nosso Senhor Jesus Cristo". Em Aurora do Campeiro, na porta da casa que serviu de residência episcopal, havia uma placa em que se lia "Orora do Campeiro". Em Cáceres, o padre Cassimiro Ponce também tinha o vício da pronúncia "defeituosa”, detalhe que faz com que fosse sempre censurado, em virtude de ocupar um cargo e por ser clérigo.

A inevitável aproximação espacial e o contato íntimo entre o bispo com os diocesanos foram acompanhados pela construção de distanciamentos irremediáveis. D. Carlos, por ter sido o primeiro bispo a empreender uma visita, foi alvo de atenção de todos e atraía curiosos e admiradores. A maioria das pessoas "queriam por que queriam aproveitar a ocasião, fartar-se de vê-lo e ouví-lo, indenizar-se com usura”, sendo de todas as idades, sexos e classes sociais (LUZ, 1979, p. 70, 128). Muitos desejavam vê-lo por curiosidade, às vezes em momentos e horários considerados inoportunos. Algumas situações foram reprovadas, como uma entrada sem cerimônia diante do bispo e a vez em que um soldado responsável pela sentinela à porta dos locais onde D. Carlos estava trabalhando permitiu a entrada de todas as pessoas, sendo incapaz de vetá-las. Segundo Luz (1979, p. 70), por mais que tentassem convencê-lo de que o bispo tinha outros afazeres, continuava a permitir a entrada desordenada e constante de diocesanos. Ou seja, no ordenamento dos espaços de algumas residências episcopais provisórias, haveria um aposento mais reservado, símbolo de distinção, do qual o bispo era o hóspede mais ilustre, em que o privilégio de acesso ao bispo deveria ser restrito e seguir um ritual solene. A sentinela, ao permitir a entrada de pessoas no 
seu aposento ou nos locais onde estava trabalhando, impossibilitava a construção da autoridade, desrespeitava os protocolos e a etiqueta e obliterava a distinção atribuída ao bispo devido a sua posição social. Havia a exigência de reforçar as hierarquias existentes na sociedade.

A supressão das formalidades sociais abolia as distâncias e a sua posição social elevada que o separava dos demais. As lutas para conservá-las objetivava salvaguardar a existência do bispo como superior e singular. Nesse sentido, haveria uma perda de poder e prestígio e o ritual e a etiqueta ficariam sem função e conteúdo. Segundo Elias (1993, p. 226), o "grau de distanciamento e de familiaridade tinha que ser cuidadosamente medido: cada cumprimento, cada conversa revestia-se de uma importância muito superior do que era realmente dito ou feito, porque indicava a situação da pessoa” e contribuía para a formação de uma opinião sobre ela. Luz (1979) procurava cultivar e proteger as marcas distintivas dos que estavam abaixo nessa hierarquia. A sem-cerimônia dos matogrossenses tornava-se uma afronta, pois a confirmação do poder episcopal viria por meio dos comportamentos dos indivíduos diante do bispo, caso contrário a posição de poder não se efetivaria. A exigência da permissão prévia e a autorização para entrar na sala em que o bispo trabalhava seriam um privilégio, um sinal de distinção que tinha significado grandioso, sério e formal, evitando a liberalização completa da etiqueta e do cerimonial.

Na narrativa de Luz (1979), as várias residências episcopais, mesmo sendo temporárias e improvisadas, e lembrando a simplicidade das casas comuns, tornavam-se um símbolo da importância pública do bispo. Estes locais se transformavam na expressão da sua elevada posição social, da sua autoridade, da sua importância para a sociedade e símbolo da posição de poder. Era o centro do poder episcopal e, como decorrência, da obrigatoriedade do cumprimento das convenções sociais. Luz (1979, p. 70) censurava o fácil acesso à pessoa do bispo e “o desembaraço, contrário às boas maneiras”. Suas queixas eram que os cômodos reservados ao bispo eram "invadidos", estando ele cercado e "abafado no meio do 
povo", impossibilitando sua privacidade e atrasando a agenda de compromissos devido ao ingresso desordenado de pessoas. O bispo seria uma pessoa ocupada e com inúmeros "deveres a cumprir". Outros problemas ligados à acomodação do bispo eram de ordens higiênicas e salutares: a pouca circulação de ar em lugares fechados com pouca ventilação, o "mal-estar" provocado por suportar "longas horas" sentado e por ficar sem tempo para descansar (LUZ, 1979, p. 69-70).

\section{A etiqueta e o processo civilizador durante a viagem pastoral ao sul da diocese de Cuiabá}

O desconhecimento da etiqueta e das normas de convivência social dos mato-grossenses foi registrado em várias situações: muitos se assentavam "sem pedir vênia”, dirigiam-lhe as palavras sem a formalidade requerida e permaneciam de cócoras ou sentados no chão. Os tumultos gerados pela concentração de curiosos os tornavam inoportunos e indesejáveis. Os diocesanos, como nunca tinham visto um bispo, admiravam-no, contemplando sua pessoa por várias horas, desejando tocá-lo e receber sua atenção. Ao reverenciarem-no, por considerar sagrada a sua pessoa, beijavam repetidas vezes o anel episcopal e ficavam admirando-o, esquecendo-se do passar das horas (LUZ, 1979, p. 70). O encontro com o bispo deveria ser acompanhado por demonstrações de fidelidade e respeito. Porém, havia queixas de que os protocolos sociais não eram respeitados, pois os comportamentos dos diocesanos eram "contrários às boas maneiras". O desrespeito "à sua alta dignidade" revelava a "ignorância das mais triviais regras de civilidade" (LUZ, 1979, p. 70).

O homem virtuoso deveria caminhar e ter gestos suavizados, mas não lentos demais. Os gestos, as atitudes e os comportamentos individuais são aquisições sociais, fruto de aprendizagens e de mimetismos formais ou inconscientes. Os gestos não permanecem imutáveis, mas evoluem de forma imperceptível (SCHMITT, 1995, p. 141). Os corpos carregam traços do universo cultural aprendido no processo de socialização e a cultura masculina predominante definia 
o bom e o mau gesto. Quando eles distanciavam-se dos valores tradicionais atribuídos à identidade masculina, eram associados à esfera feminina e à feminilidade. Nesse sentido, gestos lentos, suaves, graciosos, sincronizados e introspectivos, considerados por Luz (1979) como civilizados, seriam interditados aos homens mato-grossenses. Os esportes, as competições, a troca de parceiras sexuais e o gosto pelas aventuras e por riscos calculados tornavam-se reservatórios de virtudes viris a serem preservadas. As atividades campeiras e o cotidiano numa região fronteiriça exigiam a valorização das habilidades físicas, da combatividade, da valentia, da bravura e do preparo às lutas. Assim, os bons gestos, distintivos do homem educado, esbarravam na cultura masculina mato-grossense.

Outro aspecto criticado foi o de tocar o bispo, por considerá-lo um representante de Deus e até um santo. Apesar disso, nas regras de civilidade não era correto ficar tão perto dele a ponto de perturbá-lo. Tocá-lo criava uma intimidade não tolerada, inclusive por razões higiênicas, ou seja, a transmissão de doenças. O homem educado deveria autocontrolar-se e não tocar com as mãos ou cheirar o que vê, deseja, ama ou odeia. Ao refinar seus desejos, tocaria apenas o que vê, com o olhar (ELIAS, 1994, p. 200). O sentimento gerado por esses comportamentos era de reprovação, de asco, de incômodo e consistia numa comprovação da má educação. A desaprovação referia-se ao fato de que o bispo não parecia tão distante para a maioria dos indivíduos, como Luz (1979) desejava que fosse.

Reverenciá-lo gerava sentimentos paradoxais em Luz (1979), tanto de admiração, por revelar o respeito e a humildade em relação ao bispo, como de desprezo ao instintivo, à simplicidade, à ingenuidade e à má-educação, aspectos que os aproximavam das crianças, dos loucos, dos indígenas, dos selvagens e dos dementes. O termo selvagem evocava um gênero de vida animal, por oposição à cultura humana. Enfim, esses comportamentos justificavam-se pelo fato de viverem num mundo restrito e isolado, reflexo da natureza hostil. Esses olhares detratores ficaram evidentes no fato ocorrido no povoado de Canga. Quando a 
comitiva chegou de surpresa, encontrou todas as casas fechadas e a porta da igreja fechada. Os moradores, surpreendidos pela visita de desconhecidos e temendo ser um grupo armado que percorria a região com a intenção de roubar, esconderam-se nas casas e nas matas. Luz (1979, p. 85) relatou que, depois de algum tempo, somente "um homem apareceu-nos. Blasonando-se de bom cristão, disse-nos que a gente do lugar nunca tinha visto um Pontífice e de medo estava socada em casa”. Esse comportamento gerou sentimentos de desprezo ao ameaçarem os fins e os objetivos da viagem pastoral. O retraimento foi atribuído ao isolamento geográfico e à dedicação à vida campestre e rústica e à simplicidade espontânea, aspectos que os tornavam acanhados, indisciplinados, tímidos e desconhecedores das regras de civilidade e das conveniências sociais inerentes aos cavalheiros diante das autoridades. Refere-se Luz sobre os “moradorezinhos" de Canga e sobre o seu "excesso de medo":

[...] a triste rotina da vida que levavam, rotina dos trabalhos ordinários, campestres, jamais interrompida e antes pelo contrário, fortificada pelo hábito de viveram isolados, convertendo-os naturalmente em homens tímidos, acanhados, avaros, da pesca e da independência e opulência rústica, e por isso mesmo desconhecedores das regras comuns de tratar quanto mais das convivências sociais devidas a cavalheiros e às pessoas como a do Exmo. Sr. Bispo. (LUZ, 1979, p. 85).

O isolamento geográfico e cultural tornava os moradores de Canga prisioneiros de valores e comportamentos já superados, que os condenavam a um estágio inferior de civilização. Esse olhar reforçava o estigma de Mato Grosso como uma região que se mantinha improdutiva pela incivilidade dos mato-grossenses, sendo eles a causa da incapacidade do progresso.

Em Corumbá, o bispo recebeu inúmeras visitas, “mormente da pobreza”, que o presentearam com galinhas, ovos e frutas. A residência episcopal teria ficado cheia com essas "ofertazinhas". A forma como entregavam esses presentes, sem "cerimônia alguma”, foi atribuída à "simplicidade e [aos] costumes" (LUZ, 1979, p. 140). Enfim, os presentes foram considerados impróprios à dignidade episcopal e os visitantes foram desprezados pelos modos e meios com que ofertavam, apesar 
de evidenciarem o respeito e a submissão conferida à pessoa do bispo (LUZ, 1979, p. 70-71).

Nas inúmeras ocasiões que envolviam a visita episcopal, os comportamentos dos mato-grossenses durante as cerimônias religiosas foram censurados. As missas seguiam os ritos tridentinos e os padres rezavam de costas, num altar distante e em latim, idioma incompreensível para a maioria. Apenas o sermão era na língua portuguesa. Na maior parte da missa, as pessoas presentes não interagiam, devendo manter uma postura de devoção, silêncio e oração. Porém, o comportamento no interior dos templos era de desinteresse e de completo alheamento em relação aos rituais, que levou ao predomínio de tumultos: o choro das crianças somava-se a outros ruídos, aos risos, aos falatórios, às brincadeiras (como a de atirar grãos de milho uns nos outros) e à movimentação permanente das pessoas. Era comum também soltarem gases onde o bispo estava presente. Em Cáceres, na despedida do bispo, os fiéis comprimiam-se para beijar o anel episcopal e alguns indivíduos soltavam gases, exigindo do cônego José Joaquim dos Santos Ferreira repreensões para restabelecer a ordem e o respeito à pessoa do bispo (LUZ, 1979, p. 128). Ou seja, quando compareciam às missas, os comportamentos eram vistos por Luz (1979) como resultado da má educação, da falta de respeito, da incivilidade predominante, da ignorância da doutrina e da legislação eclesiástica e do desrespeito aos lugares sagrados. Também era criticado o fato de poucos saberem se ajoelhar.

Tendo em vista disciplinar os comportamentos e manter a ordem, os padres e os seminaristas distribuíam-se pelo interior das igrejas e capelas para exercer pressões e contrapressões, impondo coerções, censuras e controles, a fim de que os comportamentos indevidos desaparecessem. Assim, muitos fiéis tomavam conhecimento de que essas condutas eram condenadas pela Igreja e que havia regras e normas de como se comportar no interior das igrejas e no convívio social. Os gases, por exemplo, deveriam ser retidos comprimindo a barriga para soltá-los posteriormente e longe das demais pessoas. Na despedida do bispo em Cáceres, o 
cônego José Joaquim dos Santos Ferreira impôs ordem, respeito e silêncio com "um ou dois psius" (LUZ, 1979, p. 128). De acordo com Luz (1979, p. 131), ele seria um "experimentado disciplinador, que se afligia por qualquer coisa, tendo quase sempre a paciência alterada”. A descarga emocional fora do controle, embora fosse considerada ruim e inconveniente, por não ser calculada, era justificada e aceita pela intenção de instituir a ordem durante a missa, ou seja, era planejada e havia uma moderação da emoção.

Em Miranda, foram necessárias determinação e paciência (outras qualidades do homem civilizado) para impor a ordem aos 305 crismandos. Alguns agiam "com notável indiferença, como se nenhuma ideia tivessem de Deus nem da religião". Um deles "muito afligiu-nos. Inquieto e sem modos, dando mostras de impaciência e contrariado, não queria de modo nenhum largar a cabaça que tinha na mão, e a muito custo acomodou-se à ordem e compostura em que estavam os outros" (LUZ, 1979, p. 153). Luz (1979) atribuía esses comportamentos à falta de "diretores zelosos" que os conduzissem e dessem exemplo. A permanência dessas práticas, por várias décadas, revela as dificuldades encontradas para educar, refinar e aprimorar os indivíduos, assim como as resistências que a Igreja Católica enfrentou para impor novas regras de civilidade (LUZ, 1979, p. 153-154).

Houve também aqueles que não se vestiram de acordo com a ocasião, da sua posição social e, sobretudo, diante de uma autoridade eclesiástica. O professor de Canga foi surpreendido com a chegada inesperada da comitiva episcopal e, apesar de não estar desempenhando sua função, teve seus trajes e gestos observados, registrados e censurados. Sua presença foi considerada importuna, inconveniente e impertinente: "De parte a cabeça estava bem toldada, trazia a camisa fora das calças, pernas arregaçadas, uma das mãos na cintura e sem saber onde por a outra" (LUZ, 1979, p. 86). Em vez de "fazer uma bonita figura", evidenciou que era um “mal formado mestre". Luz afirma que não sentiu "desprezo por tal professor", mas “dó, não por ele, mas pelos meninos, pobres meninos, de cuja inocência ele era sem dúvida um tirano, um verdadeiro flagelo e de cujo futuro tanto descuravam os pais confiando-os sem escrúpulo nenhum ao ensino e direção de tal mestre" (LUZ, 
1979, p. 86). O professor também foi censurado por ser áspero em sua fala com o bispo, por ser solteiro e por não ter parentes no povoado. E exclamava: "A quanto está sujeito o Pastor!", que teria suportado “compassivamente” a sua fala. Como professor, havia a expectativa, que foi frustrada, de ser católico, de comportar-se bem e de vestir-se de acordo com a sua posição social. Deveria servir de exemplo e modelo do que seria a boa educação, a fim de generalizar a etiqueta por toda a sociedade.

Em Cáceres, foi apresentada uma mulher "mal reparada de roupas”, a qual recebeu um donativo do bispo para adquirir alimentos e peças de vestuário. Suas vestes seriam impróprias para apresentar-se diante de uma autoridade eclesiástica e um sinal de falta de respeito à pessoa do bispo. Alguns proprietários de terras também não dedicavam cuidado às vestimentas e à saúde, a fim de economizar recursos, embora os tivessem em grande quantidade. Nas proximidades da fazenda Porto de Santa Rosa, vivia "um velho, casado e sem filhos, que em vez de viver à farta como um Lord, de tratar de sua saúde como um pachá, não queria senão poupar até vinténs, usando de um vestuário ultra velho, que não falava em seu favor", priorizando o acúmulo de capital, em detrimento de cuidar de si e das coisas divinas, o que teria entristecido o bispo (LUZ, 1979, p. 191).

D. Carlos, ao contrário, expressaria, por gestos nobres, calmos e refinados, a sua conduta polida, ao contrário do professor, da mulher e do proprietário de terras, nos quais tudo era vulgar. A valorização da delicadeza na fala e nos gestos era acompanhada pelo asco ao desagradável e ao inferior, que deveria ser mantido à distância. Por outro lado, Luz reforçava a imagem de D. Carlos como bispo paciencioso, educado, cortês e que tinha um autocontrole das emoções fora do comum. A cruz e o martírio faziam parte da santidade e o bispo não estaria distante de alcançá-la (LUZ, 1979, p. 86).

Em Nioaque, um indivíduo procurou o bispo na hora do almoço, tendo entrado na residência episcopal provisória, sentado numa cadeira, dobrado uma 
perna sobre a outra e acendido um cigarro. O tenente Carlos Augusto Peixoto de Alencar o repreendeu por portar-se com demasiada liberdade e ele foi convidado a retirar-se do recinto: "[...] mostrando-lhe no mapa da sala a serventia desta para a praça, deu-lhe voz de: direita volver, marche e rua. O sujeito desconcertou-se e foise para não mais” (LUZ, 1979, p. 192-193). O comportamento desse indivíduo foi interpretado como resultado da sua má educação e incivilidade. Ele errou ao procurar o bispo em horário inapropriado (do almoço), ao entrar na residência episcopal sem pedir licença, ao não demonstrar respeito à autoridade eclesiástica, ao sentar, ao dobrar a perna, ao acender um cigarro e ao não saber cumprimentar o bispo. Esses comportamentos despertaram sentimentos de asco, repugnância, incômodo e desagrado por parte do clero e dos militares presentes. Coube ao tenente Alencar a missão de retirá-lo, poupando o bispo de se indispor com o tal indivíduo. Essa passagem descrita no relatório é pedagógica: era uma exigência social o respeito às autoridades, sendo obrigação dos indivíduos, por iniciativa própria, incorporar boas maneiras; caso contrário, experimentariam constrangimentos em virtude da sua má educação e falta de polimento.

Em Miranda, D. Carlos procurou atrair indígenas das etnias Terenas e Kimikinaos. Alguns andavam pela vila completamente nus, enquanto outros estavam parcial ou totalmente vestidos, a fim de comercializarem produtos agrícolas, como farinha de mandioca, peneiras, balaios, caixas e tecidos. Ou seja, havia uma despreocupação em mostrarem-se nus e em satisfazerem suas necessidades corporais na frente dos outros. Entre essas etnias e as populações não indígenas, existiam padrões diferentes em relação ao corpo, à nudez, à sexualidade e à vergonha. No olhar de Luz (1979, p. 152-153), a liberdade cômoda de uns, a rusticidade do vestuário de outros e as pinturas corporais comprovavam sua inferioridade, selvageria, rudeza, animalidade e barbárie. Eram vistos como remanescentes de um estágio já ultrapassado pela humanidade e, pela situação de aviltamento e ignorância em que permaneciam, condenavam a si e à sociedade mato-grossense ao retrocesso. Numa sociedade civilizada, apresentar-se nu e despir-se na frente dos demais era objeto de proibição e gerava sentimentos de 
vergonha, asco, repugnância, além de ser considerado pecado. A exposição da nudez, banida da vida social civilizada e confinada à intimidade por decoro e pudor, representava, nesta circunstância, falta de respeito que não merecia benevolência. Luz (1979, p. 153) testemunhou que sentiu "uma fealdade repugnante" devido a "tanta liberdade no vestuário". Os que cobriam os órgãos genitais "decentemente" com uma "rede miúda e elástica ou com uma franja larga de linha de pita e algodão" foram elogiados, pois essa era feita com "gosto e arte". Porém, continuavam a "vegetar no mesmo embrutecimento rude e silvestre", devendo ser retirados da situação de aviltamento e integrados à nacionalidade, cristianizados e civilizados (LUZ, 1979, p. 153).

Esse acontecimento colocou D. Carlos diante de uma situação considerada constrangedora, pois era celibatário e, provavelmente, nunca tinha visto uma mulher nua. Luz (1979, p. 153), ao conferir importância ao fato, selecionando-o para registrar e, após, publicá-lo, tinha como objetivo reforçar a imagem do bispo como um indivíduo civilizado. Ser tolerante, recatado e cortês diante de situações inesperadas constituía-se na principal característica da civilidade. Ou seja, os indígenas foram recebidos sem que houvesse pressão para que desaparecesse o hábito de nudez e foram presenteados com "diversos mimos”, tais como espelhos, cruzes douradas e rosários. O bispo, por outro lado, teve de exercitar, como homem, o autocontrole frente à nudez feminina e não demonstrar interesse ou curiosidade.

As visitas pastorais eram um meio de recristianização social, embora a comitiva permanecesse pouco tempo em cada local. Era um intenso período de cerimônias religiosas, em que todos os sacramentos eram administrados a fim de sensibilizar os indivíduos à prática religiosa. A população era convocada a regularizar sua situação perante a Igreja Católica, sobretudo aqueles que não estavam em dia com as determinações da Igreja. Ou seja, o êxito da visita dependia da adesão da população. 
As tentativas de disciplinar os indivíduos ocorreram em todo o percurso da visita episcopal, cujo objetivo era purificar a sociedade como um todo. Como resultado da viagem, na interminável luta entre o bem e o mal, a fé católica e o obscurantismo, houve, segundo o relatório, conquistas estrondosas. Foram realizados

[...] 500 casamentos, entrando neste número montes de amancebados que romperam de vez com as uniões ilícitas; outras uniões repararam seus erros e se reuniram; foram distribuídas muitas centenas de rosários, grande quantidade de estampas religiosas, orações impressas, medalhas e cruzes (LUZ, 1979, p.70-71).

Nos 200 sermões, nas 15.000 confissões e nos 12.000 indivíduos crismados, houve a preocupação de impor novos padrões de moral e de costumes. Luz acreditava no progresso e na civilização de Mato Grosso, além de os nativos engrenarem-se em um processo constante e inevitável, em que o catolicismo teria uma posição de destaque na sociedade. Ou seja, o homem se civilizava e isso seria positivo, pois o convívio social exigia a aceitação de regras sociais cada vez mais exatas.

Outro aspecto observado por Luz (1979), e que estava relacionado à civilidade e ao progresso de Mato Grosso, era a qualidade das residências, dos móveis e dos utensílios domésticos. Muitas casas onde o bispo se hospedara não ofereciam conforto. Em Canga, povoado considerado o mais feio de Mato Grosso, serviu de residência uma casa muito precária que tinha

[...] dois quartinhos fechados por quatro paredes de barro sem reboco, mas só foi possível fazer-se a limpeza de um deles, do destinado ao Sr. bispo, continuando o outro tal qual se achava - com os recantos cobertos de garrafões usados, fumo etc., tendo suspensos ao telhado dois girãos de carne seca e outras burundangas (LUZ, 1979, p. 86).

Luz (1979) olhava com desprezo as moradias rurais e a vida no campo, um ambiente nostálgico, rústico, de vida simples, pura, pouco confortável, sem as exigências da etiqueta da boa sociedade e oposta à vida nas cidades. A urbanização, ao contrário, geraria uma sociedade mais refinada, diversificada e rica em 
intercâmbios. Entre o campo e a cidade haveria estilos de vida, interesses, características e estágios de civilidade diferentes e irreconciliáveis. No relato, em oposição à vida urbana, à vida campesina não são atribuídas apreciações de que ela fosse ideal e mais afeita às normatizações do catolicismo, sendo até mesmo entendida como desvirtuadora da doutrina, artificial, pecaminosa e turbulenta.

As descrições das moradias na região sul de Mato Grosso evidenciam que eram, em sua maioria, edificações simples, de pau a pique e sem reboco, cobertas com capim e palha, com poucas divisórias e sem assoalho. Estas técnicas construtivas tinham baixo custo e eram adaptadas às condições climáticas e aos materiais existentes na região. Havia diferenciações entre ranchos e casas, em razão do número de peças e do tipo de telhado, e não em virtude da técnica construtiva. Os ranchos tinham pequena quantidade de peças, em geral apenas duas.

As técnicas construtivas, o descaso com o acabamento, a sobriedade mobiliária e o pouco conforto da maioria das casas foram atribuídos ao isolamento geográfico e cultural, à rusticidade predominante, à falta de sofisticação e à vida "natural" e atrasada do campo, que condenavam os mato-grossenses a um estágio inferior de civilização e de avançado atraso tecnológico. Esta precariedade na infraestrutura gerava sensações de repulsa, desagrado, repugnância, angústia e nojo pelas condições de higiene, asseio e iluminação, que comprometiam sua salubridade, sendo consideradas indignas para o bispo pernoitar ou permanecer alguns dias. Por outro lado, essas descrições consolidavam a imagem do bispo como um homem simples, humilde, sem exigências de luxo e conforto, apesar de ser um importante dignitário da Igreja Católica.

As casas mais abastadas eram construídas com madeira, cobertura com telhas de barro, tinham muitos compartimentos, varandas, móveis, decorações e variados utensílios domésticos, podendo ser consideradas luxuosas para os padrões da época. Algumas tinham jardins e pomares. Quando eram cobertas com 
telhas, tinham áreas separadas para os hóspedes, muitos móveis, utensílios domésticos e uma decoração sofisticada, não sendo apenas para o deleite e conforto dos moradores, mas eram maneiras de demonstrar o requinte, a distinção e a opulência do seu proprietário. Em Poconé, a casa onde o bispo residiu "estava vistosa e luxuosamente preparada, apresentando entre os móveis que a enchiam, grande variedade de acessórios artísticos e elegantes” (LUZ, 1979, p. 90). Na fazenda Porto de Santa Rosa, a casa foi considerada ótima:

[...] bem construída, espaçosa e ornada de elegantes móveis. Os cômodos são excelentes e tão convenientemente divididos, que sendo ocupados por hóspedes, ficam estes inteiramente independentes da família. [...] A fazenda é aformoseada por árvores frondosas e circundada por muitas fruteiras, notando-se muito gosto nas partes componentes dessa bela morada" (LUZ, 1979, p. 173).

Na fazenda Passa-Tempo, a "casa de vivenda é boa e espaçosa, tem o pavimento quase todo assoalhado e estava pintada de novo" (LUZ, 1979, p. 178).

Luz (1979) raramente descreveu em detalhes os móveis que encontrou nas residências. Muitas delas eram quase desprovidas de mobília, enquanto outras, mais raras, eram confortáveis e ornadas de “elegantes móveis” (LUZ, 1979, p. 173). Outro aspecto comum era a pequena quantidade de decorações e de utensílios domésticos nas casas. Em Aurora do Campeiro, por exemplo, "não havia mesa nem assentos”, obrigando o bispo, o clero e os seminaristas a sentarem-se sobre um couro (LUZ, 1979, p. 179). Devido ao calor, preferia-se em Mato Grosso dormir em redes e sentar-se sobre esteiras ou couros no chão. Durante a maior parte da viagem, D. Carlos e todos os participantes da comitiva episcopal dormiram em redes embaixo de árvores ou em casas abandonadas, sendo as refeições realizadas na relva e sobre uma toalha (LUZ, 1979, p. 193).

As cozinhas eram construídas em locais afastados da casa, para evitar incêndios, e a maioria tinha poucos objetos e eram raras as que possuíam pratos, talheres, panelas de ferro e copos. Em Aurora do Canteiro, por exemplo, no café da manhã havia uma única xícara, que percorreu de mão em mão (LUZ, 1979, p. 179). 
Compartilhar facas e sorver em conjunto o tereré6, por exemplo, era comum na região e poucos se importavam com isso. Porém, gerou em Luz (1979) uma sensação desagradável de medo, nojo e repugnância, por razões higiênicas e por saber que certas doenças eram transmitidas pelo uso compartilhado de objetos. Assim, compartilhar a xícara era considerado prejudicial à saúde.

Muitos indivíduos, que eram grandes proprietários de terras e de alguns escravos, residiam em casas simples, com poucos móveis e utensílios de cozinha e comiam sem o uso de talheres. O churrasco, por exemplo, exigia apenas a utilização da faca para cortar a carne e a maioria dos homens portavam uma faca, não havendo proibições e restrições sociais que limitassem seu uso. Causaram estranheza a Luz (1979, p. 180) os hábitos alimentares, em particular, o gosto pelo churrasco, “comida predileta daquela gente”, que era saboreado com as mãos.

Outro problema à mesa que denunciava a ignorância da etiqueta era o de comer até fartar-se. Em Cáceres, os camaradas Manoel, Daniel e João Grande foram dispensados por indisciplina e por desrespeito aos cônegos José Joaquim dos Santos Ferreira Santos e Bento Severiano da Luz e ao tenente Carlos Augusto Peixoto de Alencar e puderam regressar a Cuiabá. O camarada Manoel, por exemplo, foi considerado pouco afeito ao trabalho, destituído da virtude da temperança e de um apetite incomum. Segundo Luz (1979, p. 131) "logo cedo o que queria era rechear o ventre, abarrotar-se de comida, para o que tinha um estômago a toda prova, pois sendo um grande chorão comia de tudo e a qualquer hora, e nada lhe fazia mal”. As intrigas e desentendimentos aumentavam as tensões e rivalidades entre os viajantes. O tenente, para puni-lo, obrigava Manoel a despachar a bagagem antes dos demais e o privava do desjejum (LUZ, 1979, p. 131). As boas maneiras à mesa exigiam moderação no apetite e uma conduta refinada.

\footnotetext{
${ }^{6}$ Bebida típica do Paraguai, muito consumida no sul de Mato Grosso. É feita com a infusão da erva-mate (ilex paraguariensis) em água fria e servida num recipiente feito com chifre de bovino. É uma herança cultural dos indígenas Guarani.
} 
Apesar de a viagem ser repleta de dificuldades e sacrifícios, D. Carlos foi cercado de requintes, confortos e cuidados, próprios dos negócios estratégicos da Igreja Católica. Ao bispo, eram reservados os melhores cavalos e a comitiva sempre era bem recebida: todos se esmeravam em atendê-los em todas as suas necessidades (LUZ, 1979, p. 156, 161). D. Carlos tornou-se o centro de alocuções, recitais, chás, saraus, jantares, serões, reuniões comemorativas e abolicionistas, recebeu títulos beneméritos e mensagens de agradecimento e de obediência sem reservas. Por toda a viagem o bispo foi homenageado com demonstrações sempre pródigas de gratidão, reconhecimento, veneração, “acatamento, adesão e amor”, sobretudo por ter "procurado reunir as [ovelhas] que nunca tinham sido rebanhadas". Cartas e poemas eram lidos, concertos musicais foram organizados, discursos foram proferidos e brindes erguidos para valorizar a iniciativa de realizar a viagem pastoral, superando os riscos, sacrifícios e privações para difundir o catolicismo (LUZ, 1979, p. 177). A população de Campos de Vacaria mandou confeccionar, no Rio de Janeiro, um cálice de ouro, cravejado de ametistas, com valor estimado em 1:400\$ooo (LUZ, 1979, p. 176). Ou seja, Mato Grosso também tinha sua faceta educada, eficiente, sofisticada, polida, luxuosa e elegante.

Muitos indivíduos, em geral grandes proprietários de terras e escravos, foram elogiados pela polidez, cortesia, amabilidade, urbanidade, delicadeza, honradez e boa educação. Ou seja, por comportamentos de homens altamente civilizados. Antônio José da Costa, morador de Casa Nova, foi considerado um "homem franco e de boas maneiras"; e D. Anna da Silva Tavares, proprietária da fazenda Boa Vida, onde a comitiva hospedou-se, foi considerada digna de veneração e "nada deixou a desejar na hospedagem”. Já Feliciano Leopoldo Alves da Costa, genro de D. Anna, foi elogiado por ser “moço laborioso, ativo, inteligente e cavalheiro mui distinto, que esmerou-se em tratar-nos com toda a qualidade e distinção" (LUZ, 1979, p. 80-81). No povoado denominado Cotia, o alferes Antonio Paes de Proença, sua mãe e irmãos "trataram a S. Exa. com tal carinho e a nós com tanta delicadeza, que não houve uma falta a notar-se na hospitalidade que tivemos” (LUZ, 1979, p. 83). Em Cáceres, o Tenente-Coronel Gabriel Alves da 
Cunha tinha os "modos francos, bem a mais não ser" (LUZ, 1979, p. 102). Na fazenda Jacobina foram acolhidos "com grande urbanidade" e a casa tinha "bons cômodos e franqueza e generosidade em tudo" (LUZ, 1979, p. 107). Em Forquilha, Antonio da Costa Maranhão e sua esposa Francisca Candida receberam os viajores "com demonstração de benevolência e alto apreço" e foram "incansáveis em dar assinaladas mostras a provas de sua satisfação e prazer. Todos os cômodos nos foram proporcionados" e Dona Francisca “teve a fineza” de presentear o bispo com uma almofada bordada a retrós, com sofisticado acabamento (LUZ, 1979, p. 161). Na fazenda Porto de Santa Rosa, propriedade de João Caetano Teixeira Muzi, a comitiva foi recebida "com um cavalheirismo exemplar" e, na segunda passagem da comitiva pela fazenda, todos os cuidados transformaram "os aborrecimentos de uma fadigosa viagem num paraíso de delícias. De antemão combinavam as coisas tão bem que estiveram ao abrigo de qualquer surpresa” (LUZ, 1979, p. 173, 189).

As boas maneiras e a cortesia seriam virtudes de indivíduos educados e civilizados, quando em sua conduta não poupavam esforços para servir o outro em todas as suas necessidades, até o máximo de suas capacidades, por considerar que o bispo merecia estima e consideração. Na fazenda Passa Tempo, o "dono da fazenda, Sr. Tenente Joaquim Gonçalves Barbosa Marques e sua digna consorte a Exma. Sra. D. Eufrosina Garcia Leal rodearam o Sr. Bispo de grandes atenções, muita bondade e franqueza. A hospedagem preparada foi tão boa” (LUZ, 1979, p. 175). No povoado de Lagoa, a comitiva foi recebida por José Tomaz da Cunha que "desvanecidamente cumpriu seu dever o que foi muito auxiliado pelas boas maneiras de sua gentil consorte a Exma. Sra. D. Josefa Benedita de Jesus" (LUZ, 1979, p. 180-181). Em Cabeceira da Vacaria, Francisco José Pereira e sua esposa Candida Maria de Almeida, filhos e genro "nos trataram com tanta bondade e muito gosto" (LUZ, 1979, p. 187-188). No sítio Ar Novo, de João Gonçalves Barbosa, Luz (1979, p. 188) afirma que "fomos muito bem tratados". Na freguesia de Santo Antonio, os responsáveis pela hospedagem, foram elogiados pela bondade, pelos nobres sentimentos, pelas virtudes e pela franqueza ao 
obsequiarem D. Carlos e a comitiva (LUZ, 1979, p. 196).

Durante todo o percurso, houve também momentos de lazer, tendo sido oferecidos alguns jantares a D. Carlos e aos principais membros da comitiva. Também participavam pessoas importantes, tais como autoridades civis, militares e a elite local. Houve casos de ilustres convidados não saberem utilizar garfos, facas e copos à mesa (LUZ, 1979, p. 185). Para Luz (1979), não saber se comportar à mesa e não dominar o uso de talhares denunciava a má-educação desses indivíduos. Ou seja, o desagrado e o incômodo se referiam a um grupo seleto, cuja expectativa era que se fosse educado, sofisticado e se tivesse boas maneiras à mesa, por razões de higiene e civilidade. Esses indivíduos passaram por constrangimentos, apuros e embaraços ao tentarem agir de forma refinada durante esses jantares e viram-se na contingência de ter de adotar tais padrões sociais. Para Luz (1979), essas formas de conduta eram condenáveis e um desrespeito à pessoa do bispo, sendo incompreensível o porquê de ainda não estarem disseminadas na sociedade.

\section{Conclusão}

As visitas pastorais tinham muitos objetivos, entre eles a difusão de novos padrões de hábitos, de costumes e de comportamentos, a fim de instaurar a boa educação e a etiqueta, ou seja, normas sobre como fazer ou não fazer determinadas atividades, como vestir-se, falar e comportar-se. A moderação, o recato, o medo, a repugnância, a vergonha, o pudor, a culpa, as emoções mais moderadas, a delicadeza e o autocontrole individual foram difundidos para instituir mudanças e para impor novos padrões de sentimentos e de conduta. A má educação, a falta de polimento e de urbanidade e a incivilidade foram combatidas, censuradas, disciplinadas e punidas para desparecerem, a fim de que novos comportamentos fossem internalizados, visando ao refinamento dos costumes. 
Havia a exigência de que Mato Grosso se tornasse civilizado, educado, culto e elegante; para Luz (1979), essas características eram restritas a uma minoria. Os comportamentos humanos deveriam ser moldados e aperfeiçoados, devendo ter como referência a doutrina e os ensinamentos da Igreja Católica. Como afirma Elias (1993, p. 274), “o processo civilizador está em andamento” e em Mato Grosso não estava completo. Para tirar os mato-grossenses do aviltamento em que nasciam e permaneciam, era necessária uma motivação que os impulsionassem ao processo civilizatório. O processo civilizador ocorre lentamente e em longo prazo, “ora mais lentas ora mais rápidas” (ELIAS, 1994, p. 248-250). Um clero numeroso e devotado foi considerado o principal meio de realizar essa tarefa.

Para Luz (1979, p. 201), a visita teria sido vitoriosa, pois dirimiu “dissenções domésticas, resolveu dúvidas de consciência, desarraigou vícios e plantou virtudes", ou seja, "Pertransiit benefaciendo" (propagou o bem). Ao mesmo tempo, foram atribuídas imagens variadas e paradoxais a Mato Grosso, que foram incorporadas a sua identidade. No final dessa viagem, tanto os membros da comitiva, quanto os mato-grossenses foram, de alguma forma, transformados por essas experiências.

A curta permanência da comitiva episcopal em cada local não permitia uma instrução plena, mas foi importante para aumentar as exigências de civilidade. Todavia, a Igreja Católica continuou a enfrentar inúmeras resistências, pois os mato-grossenses se recusavam a internalizar as normas católicas, a demonstrar publicamente sua fé e a aceitar as regras de civilidade e de etiqueta.

Ao retornar a Cuiabá, após cinco meses e vinte e um dias, D. Carlos foi recebido como herói, com homenagens do presidente, do vice-presidente e das autoridades civis, militares e religiosas e da população. Para Luz (1979, p. 201), o bispo recebeu inúmeras demonstrações da estima, apreço, submissão e profunda reverência que possuía dos diocesanos. D. Carlos teve sua imagem reforçada como pastor dedicado que, à semelhança de Jesus Cristo, era paciente, prudente, de 
comportamentos polidos e que sofria para não desagradar a menor das ovelhas (LUZ, 1979, p. 70). Ele seria um homem superior, distinto, gentil, cortês, que dominava a civilidade e que adotava a etiqueta e o cerimonial em todas as circunstâncias, tendo uma conduta civilizada e refinada. Sua boa educação tornava ainda mais manifesta sua dignidade, sua posição hierárquica e sua autoridade sobre a condução dos assuntos religiosos em terras mato-grossenses. Essa construção da identidade episcopal entrecruza-se com a aceitação ou a recusa dessas representações, pelos outros. Nesse jogo, outras identidades e representações podem ser percebidas e atribuídas ao bispo, bem diferentes daquelas propostas por Luz (1979).

\section{REFERÊNCIAS}

BLOCH, Marc. Os reis taumaturgos. São Paulo: Cia das Letras, 1993.

ELIAS, Norbert. O processo civilizador: uma história dos costumes. Rio de Janeiro: Jorge Zahar Ed., 1994. 1 v.

ELIAS, Norbert. O processo civilizador: formação do Estado e civilização. Rio de Janeiro: Jorge Zahar (ed.), 1993. 2 v.

ELIAS, Norbert. A sociedade de corte: investigação sobre a sociologia da realeza e da aristocracia da corte. Rio de Janeiro: Jorge Zahar Ed., 2001.

FOUCAUlT, M. Microfísica do poder. Tradução de Lígia M. Pondé Vassallo. Rio de Janeiro: Graal, 1979.

GEERTZ, Clifford. Local Knowledge - Further essays in interpretative anthropology. Nova York: Basic Books, 1983.

GEERTZ, Clifford. Negara: o Estado teatro em Bali. Lisboa: Difel, 1985.

KANTOR, Iris. Pacto festivo em Minas colonial; a entrada triunfal do primeiro bispo na sé de Mariana. Dissertação (mestrado em História). São Paulo: Universidade de São Paulo, 1996.

LEITE, Luiz P. Pereira. Bispo do Império. São Paulo: Resenha Tributária, 1979.

LUZ, Bento Severino da. Visita Pastoral ao sul da diocese. In: LEITE, Luiz P. Pereira. Bispo do Império. São Paulo: Resenha Tributária, 1979. p. 67-201. 
MARIN, Jérri Roberto. Recristianização e civilização dos sertões mato-grossenses: A visita pastoral de D. Carlos Luiz D'Amour ao sul da diocese de Cuiabá, em 1886. In: MARIN, Jérri Roberto; VASCONCELOS, Cláudio Alves (org.). História, Região e Identidades. Campo Grande: Editora da UFMS, 2003. p. 183-214.

MESQUITA, José de. Monsenhor Bento Severiano da Luz; ensaio biográfico. Revista do Instituto Histórico de Mato Grosso, Cuiabá, Ano IX, Tomos XVII - XVIII, 1927.

SCHMITT, Jean-Claude. A moral dos gestos. In: SANTANA, Denise Bernuzzi de (org.). Políticas do corpo: elementos para uma história das práticas corporais. São Paulo: Estação Liberdade, 1995. p. 141-157.

SOUZA, Laura de Mello e. Desclassificados do Ouro: A pobreza mineira no século XVIII. São Paulo: Graal, 1982.

VIEIRA, Dilermando Ramos. O processo de reforma e reorganização da Igreja no Brasil (1844-1926). Aparecida, SP: Ed. Santuário, 2007. 